\title{
High Arctic Mytilus spp.: occurrence, distribution and history of dispersal
}

\author{
Peter Leopold ${ }^{1,2}$. Paul E. Renaud ${ }^{2,3} \cdot$ William G. Ambrose Jr. ${ }^{3,4} \cdot$ Jørgen Berge ${ }^{1,2,5}$
}

Received: 14 February 2018 / Revised: 29 September 2018 / Accepted: 1 October 2018 / Published online: 16 October 2018

(c) The Author(s) 2018

\begin{abstract}
Many marine species are known to change their distribution in response to changing climatic conditions. One such example is the blue mussel Mytilus spp., spreading northward coincident with an increase in ocean temperatures. On Svalbard, the first living specimens of Mytilus spp. were discovered in 2004. Here we present an analysis of the current distribution of Mytilus spp. on Svalbard, with a focus on the west coast of Spitsbergen where strong Atlantification has been documented over the last few decades. We conducted diver-based surveys to develop a distributional map and to compare the current distribution with that of the Holocene. Furthermore, we investigate the recent history of recruitment of mussels on Svalbard to help identify invasion pathways. Our results show that blue mussels have been present on the archipelago at least since 2000 and are widespread along the west coast today. We also present evidence of local reproduction in one of the sites explored.
\end{abstract}

Keywords Bivalves $\cdot$ Climate change $\cdot$ Arctic $\cdot$ Holocene Mytilus spp. $\cdot$ Range extension

\section{Introduction}

Blue mussels of the genus Mytilus are commonly found in intertidal and subtidal habitats in both hemispheres (Koehn 1991; Gosling 1992). They display an antitropical distributional pattern, occurring only in mid- and high-latitudes (Hubbs 1952). Mytilus spp. play important roles ecologically (as ecosystem engineers) and commercially (in the shellfish industry) and have the potential to dominate benthic

Electronic supplementary material The online version of this article (https://doi.org/10.1007/s00300-018-2415-1) contains supplementary material, which is available to authorized users.

Jørgen Berge

jorgen.berge@uit.no

1 Faculty of Biosciences, Fisheries and Economics, UiT The Arctic University of Norway, 9037 Troms $\varnothing$, Norway

2 University Centre in Svalbard, $\mathrm{Pb} 156,9171$ Longyearbyen, Norway

3 Akvaplan-niva, Fram Centre, 9296 Troms $\varnothing$, Norway

4 School of the Coastal Environment, Coastal Carolina University, Conway, SC 29578, USA

5 Department of Biology, Centre of Autonomous Marine Operations and Systems (AMOS), Norwegian University of Technology and Science (NTNU), Trondheim, Norway ecosystems in intertidal and shallow subtidal habitats (Seed 1969; Gosling 2003). Although they tolerate a broad spectrum of environmental conditions (e.g. temperature, salinity, predation and pollution), they are commonly used as climate indicators with winter air temperature being one of the main factors limiting their distribution (Salvigsen et al. 1992; Hjort et al. 1995; Dyke et al. 1996; Salvigsen 2002; Berge et al. 2005; Thyrring et al. 2015). Perhaps as a consequence of limiting winter temperatures, Mytilus rarely occur in the intertidal towards their northern distributional limit, but are generally subtidal at depths down to approximately $5 \mathrm{~m}$ (Thyrring et al. 2015; Mathiesen et al. 2017).

The Mytilus spp. complex in the Northern Hemisphere currently consists of four generally accepted and closely related species: M. edulis, M. galloprovincialis, M. trossulus and $M$. californicus. The last species is not known to occur in the North Atlantic and is, therefore, not considered in our study. Recent genetic work by Mathiesen et al. (2017) covered populations of Mytilus spp. from both the European Arctic and Greenland and found genetic markers from all three species to be present on both Svalbard and Greenland. Accordingly, we regard these three species as one complex and refer to them as 'Mytilus spp.' hereafter.

Fossil and subfossil remains of blue mussels are found throughout the Arctic and sub-Arctic region, often in areas currently not inhabited by the species (Hjort and Funder 
1974; Hjort et al. 1995; Salvigsen 2002, Mangerud and Svendsen 2018). In the high Arctic archipelogo of Svalbard, however, Mytilus spp. are starting to reoccupy their former range. In the last decade, the northern distribution limit Mytilus spp has shifted northwards (e.g. Berge et al. 2005; Thyrring et al. 2015; Mathiesen et al. 2017). Their wide distribution and fossil evidence of successful settlement further north during warmer periods of the Holocene (Mangerud and Svendsen 2018) make the genus Mytilus useful for studying the impacts of environmental changes in the Arctic. Nevertheless, there are few studies regarding Arctic populations of Mytilus spp., and little is known about their distribution, life cycle, and reproduction, or the mechanisms behind the expansion and retreat of their populations in the North. The usefulness of Mytilus spp. as a sentinel for climate change, however, depends largely on our understanding of these autecological features.

Recently, a few live sightings of single Mytilus spp. individuals have been reported from Svalbard (see Berge et al. 2005 and references therein) with most individuals attached to flotsam. Only one small subtidal population consisting of young mussels has been reported (Berge et al. 2005, 2006). One reason for the low detection of living specimens may be that shipboard sampling typically avoids shallow areas where blue mussels occur cryptically among macroalgae within the hard bottom communities. Thus, we carried out a detailed field survey with scientific divers to map the Mytilus spp. distribution along the west coast of Svalbard, an area where blue mussels display long fossil records (Salvigsen 2002). Shells of the collected samples were examined to provide insight into the age distribution and recruitment frequency in Svalbard populations. We compare our results with findings from other living and fossil Mytilus spp. within the Atlantic-Arctic region to gain a fuller understanding of the population connectivity of Atlantic Mytilus spp. and to assess their potential for continued expansion on Svalbard.

\section{Materials and methods}

Examination of the mussels was carried out in the laboratory and included biometric analysis and age determination (based on winter growth checks on the external shell surface see Blicher et al. 2013). To test whether external growth lines are deposited annually in the Svalbard area, we placed marked individuals back in the field for 1 year. Twenty-one Mytilus spp. individuals were collected at Mitraskjæret (Kongsfjorden). The mussels were kept for 10 days in seawater onboard the research vessel Helmer Hanssen. During this period, they were stained with calcein dye for $20 \mathrm{~h}$ (see Gillikin et al. 2006 for further details) before being placed in cages on ocean observatories. Eleven individuals were placed in Kongsfjorden (primarily an Atlantic Water fjord), and 10 individuals were placed in Rijpfjorden (primarily an Arctic Water fjord) at $15 \mathrm{~m}$ depth in September 2011 (see Cottier et al. 2005; Berge et al. 2009). The mussels were retrieved from the moorings in August 2012. The right valve of each individual was embedded in epoxy, cut from the umbo to the ventral margin, and polished. Cross sections were imaged using a Nikon Compound Episcopic Microscope capable of fluorescent imaging with wavelengths of $460-500 \mathrm{~nm}$. Images were used to determine the number of growth increments visible in the cross section that occurred after the calcein stain line.

Diving surveys were conducted by groups of scientific divers during research cruises around Svalbard between 2011 and 2016. We focussed on two types of habitats: (1) shallow subtidal hard substrate areas, preferably in fjordmouth locations with little sedimentation, but high current exposure, and (2) harbour areas as we considered ship traffic a possible vector of introduction of blue mussels. At each site, divers carefully examined the sublitoral between 0 and $5 \mathrm{~m}$ depth. Any Mytilus spp. specimens present were documented and photographed. Subsamples were collected at each locality by removing single individuals from the substratum with a knife and carefully placing them into a mesh bag.

We used the literature of both fossil and living Mytilus spp. around the Atlantic-Arctic region, from the Eastern Canadian Arctic to Northern European Russia to determine the extent and former ranges of Mytlius spp. Where possible, we extracted geographical coordinates and habitat information (Fig. 1; Online Resource 1).

\section{Results}

One single growth band was discernible distal to the calcein stain line in each of the 21 mussels deployed on the observatories in the two fjords (Fig. 2). The growth line was visible as an internal line that extended to the external shell surface where it manifested as a ridge. Consequently, we conclude that the growth lines are annual and will herein regard using the number of external lines on the shell as a good approximation of the age of each individual.

Our field survey recorded live Mytilus spp. at 21 locations along the west coast of Svalbard from Kongsfjorden $\left(79^{\circ} \mathrm{N}\right)$ in the north, to Dunderbukta $\left(77^{\circ} 30^{\prime} \mathrm{N}\right)$, just south of Bellsund in the south (Fig. 1, Online Resource 1). Densities were generally very low ( $<0.5$ individuals (ind.) $\mathrm{m}^{-2}$ ), but considerably higher at the two harbour sites examined in Ny-Ålesund and Longyearbyen, where densities reached 10 ind. $\mathrm{m}^{-2}$ (Table 1). In general, all individuals lived well hidden in cracks in the substrate or were otherwise densely overgrown with macroalgae (kelp, red algae) and sessile invertebrates (bryozoans, hydrozoans, cirripedians, and 
Fig. 1 Geographic location of subfossil (yellow) and living (green) Mytilus spp. in the Atlantic-Arctic region based on literature data. Enlargement showing Svalbard locations with subfossil, recent living and negative findings of Mytilus spp. (yellow, green, and red dots, respectively). Numbering is in accordance with Online Resource 1 and Table 1. Subfossil findings are based on Salvigsen (2002) and Mangerud and Svendsen (2018), whereas recent observations were made by the authors in the period of 2004-2016. Negative findings (red) are dive sites specifically surveyed for blue mussels during this period that revealed no encounter

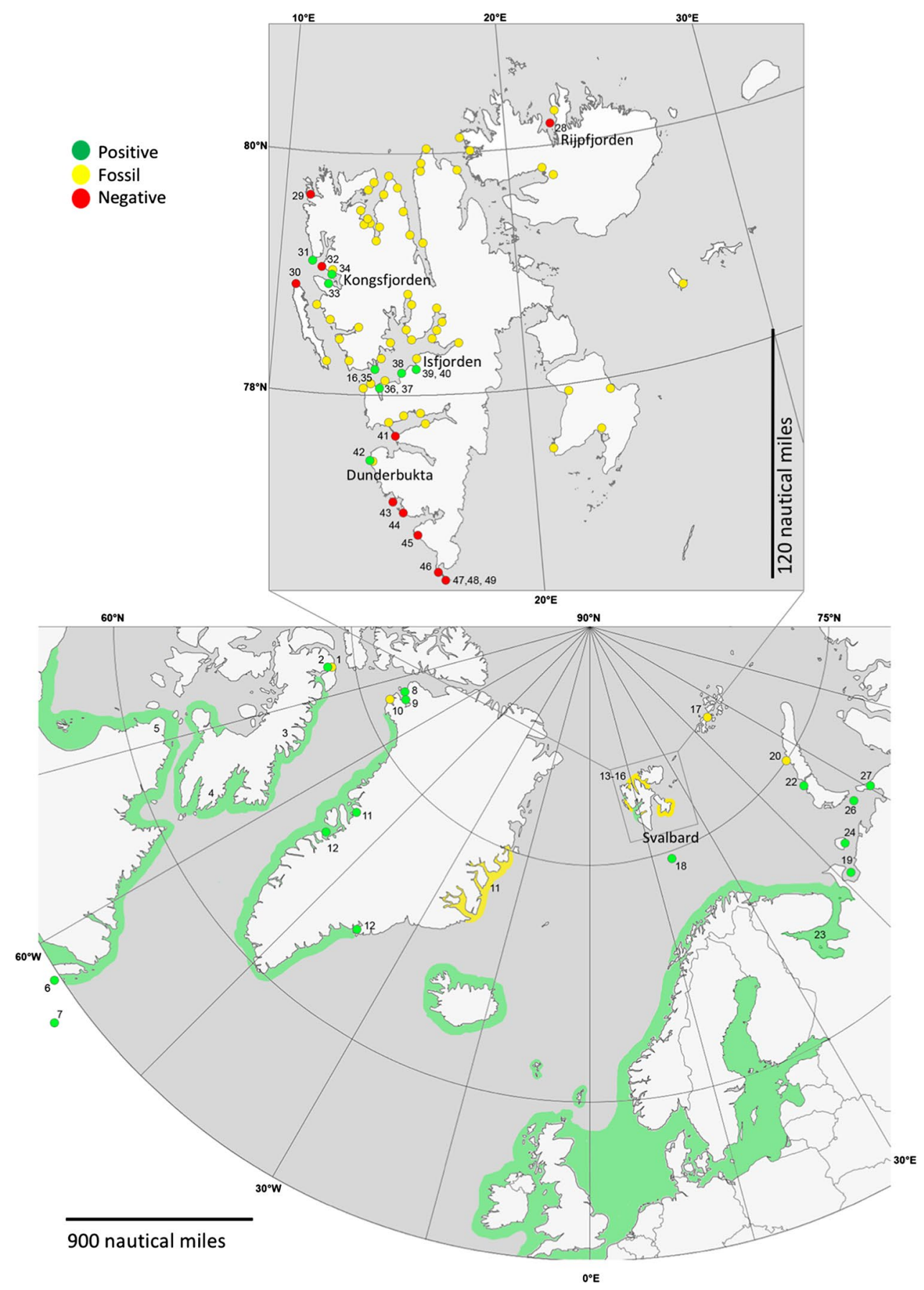

tunicates). In total, we recorded $\sim 600$ blue mussels $\geq 2$ year old during surveys conducted from 2011 to 2016, of which 328 were collected. In addition, one diver reported a single living blue mussel on the rocky slope at Fuglefjellet (just outside Adventfjorden) (P. Kuklinski pers com, see Online Resource 1). The collected individuals showed a broad range of size and age ( 8 to $88 \mathrm{~mm}$ length, 1-14 years). The reconstructed settlement year of individual mussels was estimated by subtracting the number of external (annual) growth lines from the year of collection for mussels collected inside
Adventfjorden and Kongsfjorden. This indicated recruitment every year since 2000 (Fig. 3). Although the numbers of individuals we encountered varied for the two fjords, our results clearly indicate an annual and continuous recruitment in both areas.

At one site (Longyearbyen harbour), we documented a dense patch (>400 ind. $\mathrm{m}^{-2}$ ) of 1-year-old Mytilus spp. attached to the hull of a local charter boat (M/S Ulla Rinman). The vessel's itinerary indicated that she had not left the coastal waters of the archipelago during the past 
Fig. 2 Ventral margin of Mytilus sp. from Kongsfjorden, 11 months after staining with calcine. a Calcine line under fluorescence at $\times 5$ magnification. b Ventral margin in dark field at $\times 5$ magnification. Arrows indicate location of calcein/annual line
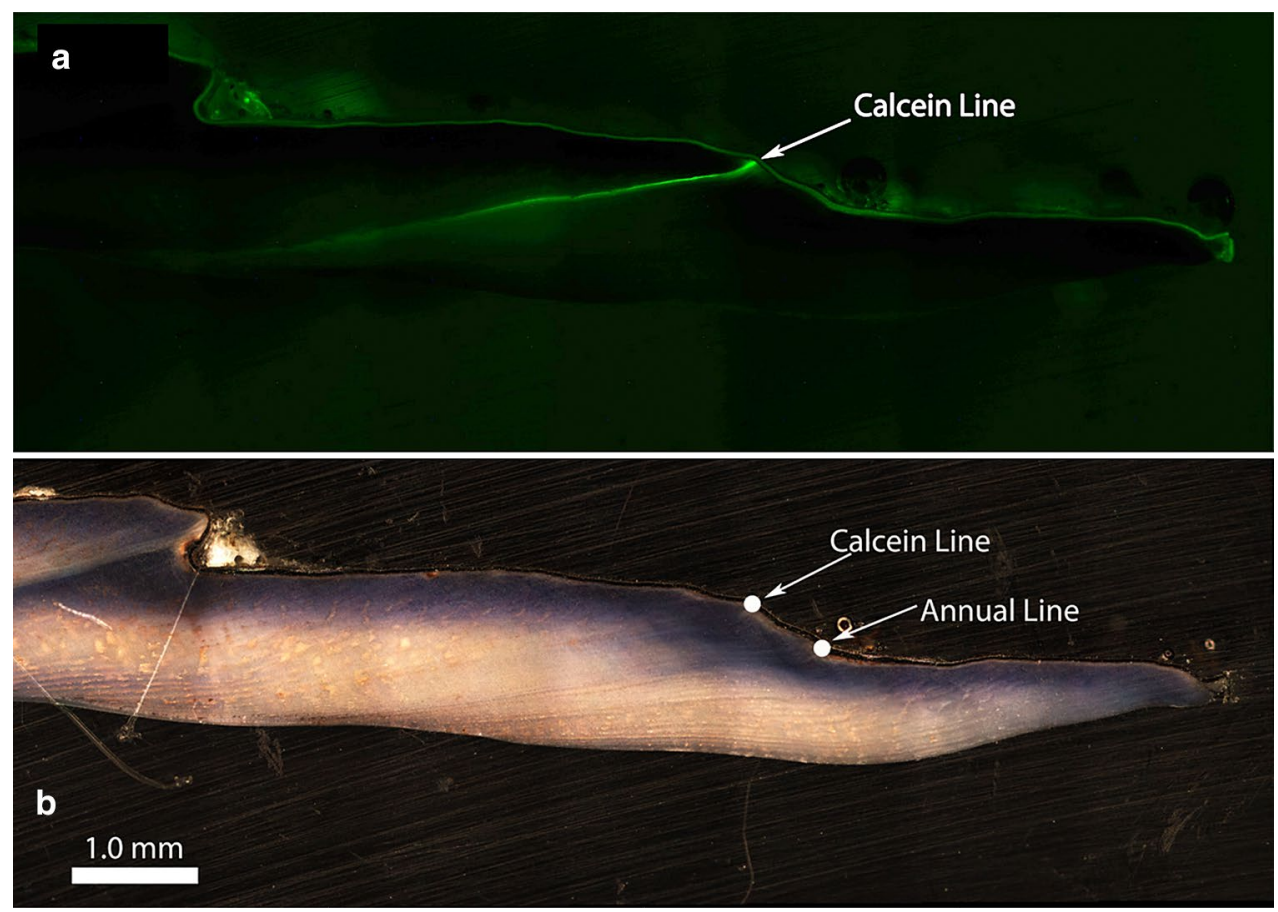

year, spending considerable time in both Adventfjorden and Hornsund (further south at around $77^{\circ} \mathrm{N}$ ).

\section{Discussion}

Based on the wide range of locations where we found Mytillus spp., we argue that blue mussels are widespread along the western Svalbard coast (Fig. 1, Table 1). So far, only Berge et al. $(2005,2006)$ has reported the existence of resident Mytilus spp. on Svalbard and only at one site (Sagasjkæret, Isfjorden). They postulated that blue mussel larvae had settled on Svalbard in 2002 and that the larvae had been transported from a source population on mainland Norway by the North Atlantic Current and West Spitsbergen Current (WSC). This was suggested to be a one-time event as all mussels found were of similar age. The oldest mussel collected in our study, however, settled around the year 2000 in Adventfjorden, right outside Longyearbyen. Despite the low densities at all sites, our data clearly show that settlement of blue mussels is a recurring event, with evidence of recruitment every year since 2000 (Fig. 3).

Mytilus spp. is often considered to be a reliable climate indicator (Salvigsen et al. 1992; Hjort et al. 1995; Dyke et al. 1996; Salvigsen 2002; Berge et al. 2005; Thyrring et al. 2015). This foundation species' wide distribution and role in structuring benthic communities render it a prime model organism for geologists and palaeontologists to reconstruct paleoclimate and for biologists to predict future marine community composition. The genus once occurred farther north than today during the warmer periods of the Holocene (roughly 9-6.5 ky BP) and died out, presumably due to direct and indirect effects of the cooling climate (Salvigsen 2002).

Shifts in species ranges and community composition of Svalbard/Barents Sea benthos have even been observed to fluctuate over the past 100 years (Renaud et al. 2007). Sea surface temperatures (SST) and sub-surface temperatures around Svalbard and off the western Barents shelf have varied during the Holocene, mostly due to the advected Atlantic Water (AW) and a northward shift in the sea ice margin. The warmest phase, referred to as the 'Holocene thermal optimum', occurred around 10.7-7.7 kyr. BP, peaking at 10.2-9.2 kyr. BP (Mangerud and Svendsen 2018). Reconstructed summer SSTs were as high as $8{ }^{\circ} \mathrm{C}$ during this period and later dropped to around $4{ }^{\circ} \mathrm{C}$ where they stabilized and persisted for $\sim 5$ kyr. (Sarnthein et al. 2003). Werner et al. (2013) showed the same trend for sub-surface water temperatures of the Atlantic Water core (50-200 m depth) at the western Barents shelf. This water mass feeds the WSC directly and is therefore responsible for the transport of warm AW to western Svalbard. Ultimately, some branches of the WSC may reach into the west-facing fjords to various extents in different years (Cottier et al. 2007). Werner et al. (2011) also showed mild warming for the last $3 \mathrm{kyr}$. and a more drastic temperature increase during the last 1 kyr. Modern (since 1900), summer sub-surface temperature ranges (50-100 $\mathrm{m}$ depth) equal the values of the Holocene thermal optimum for the western Barents shelf area. Even though the summer SSTs today around Svalbard are 
Table 1 Location, date, and brief description of Mytilus spp. sampling sites on Svalbard

\begin{tabular}{|c|c|c|c|c|c|c|c|c|c|}
\hline No. & Location & $\begin{array}{l}\text { Latitude/longi- } \\
\text { tude }\end{array}$ & Sampling date & $\mathrm{n}$ & $\begin{array}{l}\text { Length range } \\
(\mathrm{mm})\end{array}$ & $\begin{array}{l}\text { Age } \\
\text { range } \\
\text { (years) }\end{array}$ & Density (ind $/ \mathrm{m}^{2}$ ) & Habitat/comment & Depth (m) \\
\hline \multicolumn{10}{|c|}{ Nordaustland } \\
\hline 28 & Rijpfjorden & $80^{\circ} 11^{\prime} \mathrm{N} 22^{\circ} 14^{\prime} \mathrm{E}$ & 03.10 .2014 & - & - & - & - & $\begin{array}{l}\text { Exposed kelp } \\
\text { forest }\end{array}$ & \\
\hline \multicolumn{10}{|c|}{ Smeerenburg } \\
\hline 29 & Moseøya & $79^{\circ} 39^{\prime} \mathrm{N} 10^{\circ} 55^{\prime} \mathrm{E}$ & 14.09 .2015 & - & - & - & - & $\begin{array}{l}\text { Exposed kelp } \\
\text { forest }\end{array}$ & - \\
\hline \multicolumn{10}{|c|}{ Prins Karls Forland } \\
\hline 30 & Fuglehuken & $78^{\circ} 54^{\prime} \mathrm{N} 10^{\circ} 28^{\prime} \mathrm{E}$ & 15.05 .2014 & - & - & - & - & $\begin{array}{l}\text { Exposed kelp } \\
\text { forest }\end{array}$ & - \\
\hline \multicolumn{10}{|c|}{ Kongsfjorden } \\
\hline \multirow[t]{3}{*}{31} & Mitraskjæret & $79^{\circ} 07^{\prime} \mathrm{N} 11^{\circ} 08^{\prime} \mathrm{E}$ & 30.09 .2012 & 21 & n.d. & $2-8$ & $<1$ & $\begin{array}{l}\text { Exposed kelp } \\
\text { forest }\end{array}$ & $2-6$ \\
\hline & & & 03.09 .2013 & 13 & $14.5-36.5$ & $4-9$ & $<1$ & $\begin{array}{l}\text { Exposed kelp } \\
\text { forest }\end{array}$ & $2-6$ \\
\hline & & & 14.05 .2014 & 23 & $45.5-85.9$ & $6-10$ & $<1$ & $\begin{array}{l}\text { Exposed kelp } \\
\text { forest }\end{array}$ & $2-6$ \\
\hline 32 & Guissezholmen & $79^{\circ} 04^{\prime} \mathrm{N} 11^{\circ} 38^{\prime} \mathrm{E}$ & 14.05 .2014 & & & & - & $\begin{array}{l}\text { Exposed kelp } \\
\text { forest }\end{array}$ & - \\
\hline 33 & $\begin{array}{l}\text { Ny Ålesund } \\
\text { harbour }\end{array}$ & $78^{\circ} 56^{\prime} \mathrm{N} 11^{\circ} 56^{\prime} \mathrm{E}$ & 24.09 .2014 & 2 & $31.1,63.7$ & 2,6 & $<5$ & Vertical pile wall & $1-6$ \\
\hline 34 & $\begin{array}{l}\text { Bloomstrand- } \\
\text { halvøya }\end{array}$ & $78^{\circ} 59^{\prime} \mathrm{N} 11^{\circ} 58^{\prime} \mathrm{E}$ & 29.09 .2014 & 1 & 46.3 & 7 & singe ind. & Bare rock & 2 \\
\hline \multicolumn{10}{|c|}{ Isfjorden } \\
\hline 35 & Sagaskjæret & $78^{\circ} 13^{\prime} \mathrm{N} 13^{\circ} 56^{\prime} \mathrm{E}$ & 08.2004 & 11 & $27-55$ & $2-3$ & $<1$ & $\begin{array}{l}\text { Exposed kelp } \\
\text { forest }\end{array}$ & $4-7$ \\
\hline 36 & Grønnfjorden & $78^{\circ} 06^{\prime} \mathrm{N} 14^{\circ} \mathrm{E}$ & 2010 & 2 & $\leq 43$ & $\leq 6$ & n.d. & n.d. & n.d. \\
\hline 37 & Grønnfjorden & $78^{\circ} 04^{\prime} \mathrm{N} 14^{\circ} 12^{\prime} \mathrm{E}$ & 09.07 .2016 & 1 & 33.5 & 4 & singe ind. & Vertical pile wall & 1 \\
\hline 38 & Fuglefjellet & $78^{\circ} 13^{\prime} \mathrm{N} 15^{\circ} 14^{\prime} \mathrm{E}$ & 26.07.2012 & 1 & n.d. & n.d. & singe ind. & Dense kelp forest & 6 \\
\hline 39 & $\begin{array}{l}\text { Longyearbyen } \\
\text { harbour }\end{array}$ & $78^{\circ} 14^{\prime} \mathrm{N} 15^{\circ} 36^{\prime} \mathrm{E}$ & 18.05 .2014 & 197 & $19.3-87.5$ & $2-14$ & $<25$ & Vertical pile wall & $1-7$ \\
\hline 40 & $\begin{array}{l}\text { M/S Ulla } \\
\text { Rinman }\end{array}$ & $78^{\circ} 14^{\prime} \mathrm{N} 15^{\circ} 36^{\prime} \mathrm{E}$ & 10.2014 & 120 & $7-23$ & $1-2$ & $<200$ & Rudder stock & $1-2$ \\
\hline \multicolumn{10}{|c|}{ Bellsund } \\
\hline 41 & Akseløya & $77^{\circ} 41 \mathrm{~N} 14^{\circ} 55^{\prime} \mathrm{E}$ & 10.07 .2016 & - & - & - & - & $\begin{array}{l}\text { Exposed kelp } \\
\text { forest }\end{array}$ & - \\
\hline 42 & Dunderbukta & $77^{\circ} 29^{\prime} \mathrm{N} 13^{\circ} 53^{\prime} \mathrm{E}$ & 11.07.2016 & 5 & $36.0-60.2$ & $4-10$ & $<1$ & $\begin{array}{l}\text { Exposed kelp } \\
\text { forest }\end{array}$ & $2-4$ \\
\hline \multicolumn{10}{|c|}{ Hornsund } \\
\hline 43 & Isøyane & $77^{\circ} 08^{\prime} \mathrm{N} 14^{\circ} 48^{\prime} \mathrm{E}$ & 12.07.2016 & - & - & - & - & Bare rock & - \\
\hline 44 & Dunøya & $77^{\circ} 02^{\prime} \mathrm{N} 15^{\circ} 04^{\prime} \mathrm{E}$ & 13.07.2016 & - & - & - & - & $\begin{array}{l}\text { Exposed kelp } \\
\text { forest }\end{array}$ & - \\
\hline 45 & Vestvika & $76^{\circ} 51^{\prime} \mathrm{N} 15^{\circ} 32^{\prime} \mathrm{E}$ & 15.07.2016 & - & - & - & - & $\begin{array}{l}\text { Exposed kelp } \\
\text { forest }\end{array}$ & - \\
\hline \multicolumn{10}{|c|}{ Sørkapp } \\
\hline 46 & Tokrossøya & $76^{\circ} 33^{\prime} \mathrm{N} 16^{\circ} 19^{\prime} \mathrm{E}$ & 14.07.2016 & - & - & - & - & Bare rock & - \\
\hline 47 & Sørkappøya & $76^{\circ} 30^{\prime} \mathrm{N} 16^{\circ} 28^{\prime} \mathrm{E}$ & 14.07.2016 & - & - & - & - & Bare rock & - \\
\hline 48 & Sørkappøya & $76^{\circ} 30 \mathrm{~N} 16^{\circ} 30^{\prime} \mathrm{E}$ & 14.07.2016 & - & - & - & - & $\begin{array}{l}\text { Exposed kelp } \\
\text { forest }\end{array}$ & - \\
\hline 49 & Sørkappøya & $76^{\circ} 28 \mathrm{~N} 16^{\circ} 31^{\prime} \mathrm{E}$ & 14.07.2016 & - & - & - & - & $\begin{array}{l}\text { Exposed kelp } \\
\text { forest }\end{array}$ & - \\
\hline
\end{tabular}

Numbers correspond to locations in Fig. 1 
Fig. 3 Recruitment years, estimated by number of winter growth lines on the external shell surface, and number of individuals settled for $271 \mathrm{Myti}$ lus spp. individuals collected during the years 2012-2014 on Svalbard. Samples are separated by collection sites

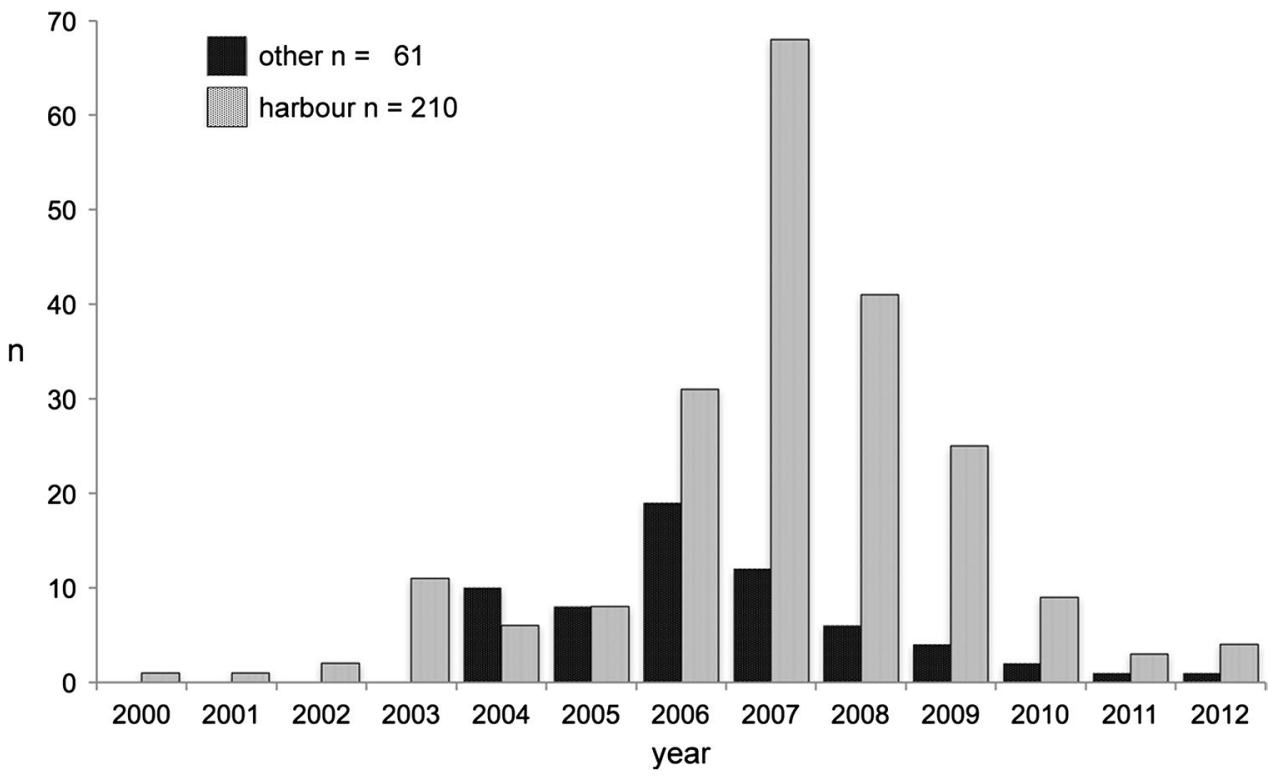

some $5-8{ }^{\circ} \mathrm{C}$ lower than during the thermal peak of the early Holocene, they are well within the temperature range when Mytilus spp. previously occupied the archipelago. The Holocene occurrence of Mytilus spp. was most likely a recurring event during intermittent warm periods (see Mangerud and Svendsen 2018, results and discussion). In summary, advection of AW and temperatures in the area around Svalbard and farther north favour the arrival, settlement, and survival of boreal species, including Mytilus spp. This is consistent with fluctuations in species distributions over at least the past $10 \mathrm{kyr}$. and has recently been shown by many authors for both pelagic and benthic species over the past 4 decades (Kortsch et al. 2012; Berge et al. 2015; Renaud et al. 2015).

There are three non-mutually exclusive scenarios that could explain the occurrence and distribution of Svalbard blue mussels today. First, they might be a relict population that descended from Holocene blue mussels. Second, they may be closely related to the Northern Atlantic M. edulis population, as proposed by Berge et al. (2005, 2006). Third, mussels could be introduced by human activity, e.g. in the form of ballast water transport (Ware et al. 2014) or attached to hulls of visiting ships. Each of these possibilities is examined separately.

If Mytilus spp. were present on Svalbard since the Holocene, the population would have had to reproduce successfully and survive throughout the notably colder (than today) temperatures of the late Holocene. The youngest (single) Mytilus subfossil from Isfjorden (Kapp Thordsen) dates from around $1 \mathrm{ky} \mathrm{BP}$ and there is a gap of almost $3 \mathrm{ky}$ to the next youngest deposits (found in Billefjorden) (Salvigsen et al. 1992). Genotypes of isolated (relict) species will diverge over time from their nearest relatives and can eventually lead to species segregation (Vermeij 1991). Also, if the
Svalbard population of mussels were isolated for at least 1 ky, we would expect its genome to be different from their closest ancestors, northern Norwegian mussels. This aspect was addressed in a study by Mathiesen et al. (2017) who investigated the genetic diversity and connectivity between Arctic and sub-Arctic Mytilus populations. Different populations of mussels from Greenland, Iceland, Russia, Norway, and some of the Svalbard specimens from this study were compared using genetic markers. Mytilus spp. from Svalbard were mainly $M$. edulis; however, some samples were classified as $M$. galloprovincalis and hybrids of both, $M$. edulis/M. galloprovincalis and M. edulis/M. trossolus. One has to keep in mind that results of genetic studies only reflect what was sampled. The absence of certain taxa or hybrids, therefore, has to be considered carefully as it may just represent undersampling. The Svalbard samples, however, clustered closest with Norwegian and White Sea samples, indicating that a colonization of Svalbard from the south is the most likely scenario for present day Mytilus spp. on Svalbard. We suggest the scenario of Mytilus being present throughout the Holocene as rather unlikely due to the lack of both fossil and recent evidence. In addition, the presence of some hybrids in our samples (Mathiesen et al. 2017) suggests a recent establishment of Mytilus spp. on Svalbard. It is unlikely that hybrids would have survived since or even been present during the Holocene warm periods. Mangerud and Svendsen (2018) conclude that Mytilus spp. likely became locally extinct on Svalbard around 3.7 ky BP and that the youngest fossil deposit is from a Medieval warm period reimmigration that may be comparable with its recent arrival described by Berge et al. (2005). Both authors postulate that advection of larvae or transport of individuals on flotsam has initially and repetitively seeded the blue mussel stock on 
Svalbard. Our finding of scattered mussel patches along the outer western coast and inside the mouth of the west-facing fjords coincides with likely drift patterns and reinforces this hypothesis. Also, the same area was subject to an intensive intertidal survey in the early 1990 (Weslawski et al.1993, 1997) without any records of living Mytilus spp, providing at least circumstantial evidence that they were not living in the area at that time.

The fact that we also find Mytilus deep inside the fjords, especially on artificial harbour structures, points towards a second vector of dispersal: ship traffic. Ware et al. (2014, 2016) did not find Mytilus spp. larvae in ballast water samples on Svalbard taken from bulk carriers originating from non-Norwegian ports. They did, however, detect several other non-indigenous species in the ballast water samples. Ware et al. (2016) point out the insufficiency of the ballast water management practices on Svalbard and that required protocols are often not followed by vessels. They conclude, therefore, that Svalbard ports are at high risk of ballast water and biofouling introductions, where currently no management regulations exist. Blue mussels are important contributors to fouling assemblages (Gosling 2003) and have been introduced to several parts of the world far beyond its native range, often through long-range maritime transport (see Beyer et al. 2017 and references herein). Adult mussels are able to detach themselves from ship hulls or spawn when inside 'foreign harbours'. We consider it likely that Mytilus spp. has been introduced by ship traffic in addition to natural advection from the Norwegian mainland.

We provide a detailed biogeographic overview of the distribution of Mytilus spp. on Svalbard, including new findings of living blue mussels along the west coast of Spitsbergen, and compare the patterns with fossil distributions from the area. Also, the finding of a dense aggregation of one-yearold Mytilus spp. (> 400 ind. $\mathrm{m}^{-2}$ ) in Isfjorden suggests that there is local reproduction on Svalbard. Although circumstantial, the mere density of settled individuals suggests that the larvae have not been transported over long distances. The occurrence of blue mussels on Svalbard is most likely the result of at least two distinct dispersal vectors: natural larval advection by ocean currents and human introduction by ship traffic. Based on the estimated year of settlement of specimens found in non-harbour locations (Fig. 3), we conclude that the settlement of Mytilus spp. is an annual, rather than unique, event as suggested by Berge et al. (2005). Combined with the circumstantial evidence of local reproduction, this implies that current environmental conditions are favourable for continued persistence of Svalbard's Mytilus spp. populations.

Acknowledgements This work was financially supported by UiT The Arctic University of Norway, The university centre in Svalbard (field support), the Fram Center project 'Life at the edge' through the 'Fjord and Coast flagship'. The Research Council of Norway provided financial and field support through the projects 'Marine Night' (nr 226417) and 'Arctic ABC' ( $\mathrm{nr}$ 244319). William Locke using the Bates College Imaging Center facilities did the fluorescent imaging. The work is a contribution of the Arctos (arctos.uit.no) and Arctic Science Partnership (asp-net.org) research networks. We thank the captain and crew of RV Helmer Hanssen and divers and field assistants Daniel Vogedes, Sanna Majaneva and Carl Ballantine for their help and support of field work. We also thank Joanne Muratori for editorial assistance.

\section{Compliance with ethical standards}

Conflict of interest There are no identified conflicts of interest regarding the work presented herein.

Open Access This article is distributed under the terms of the Creative Commons Attribution 4.0 International License (http://creativeco mmons.org/licenses/by/4.0/), which permits unrestricted use, distribution, and reproduction in any medium, provided you give appropriate credit to the original author(s) and the source, provide a link to the Creative Commons license, and indicate if changes were made.

\section{References}

Berge J, Johnsen G, Nilsen F et al (2005) Ocean temperature oscillations enable reappearance of blue mussels Mytilus edulis in Svalbard after a 1000 year absence. Mar Ecol Prog Ser 303:167-175. https://doi.org/10.3354/meps303167

Berge J, Johnsen G, Nilsen F et al (2006) The Mytilus edulis population in Svalbard: how and why. Mar Ecol Prog Ser 309:305-306

Berge J, Cottier F, Last KS et al (2009) Diel vertical migration of Arctic zooplankton during the polar night. Biol Lett 5:69-72. https://doi. org/10.1098/rsbl.2008.0484

Berge J, Heggland K, Lønne OJ et al (2015) First records of Atlantic Mackerel (Scomber scombrus) from the Svalbard Archipelago, Norway, with possible explanations for the extension of its distribution. Arctic 68:54. https://doi.org/10.14430/arctic4455

Beyer J, Green NW, Brooks S et al (2017) Blue mussels (Mytilus edulis spp.) as sentinel organisms in coastal pollution monitoring: a review. Mar Environ Res 130:338-365. https://doi.org/10.1016/j. marenvres.2017.07.024

Blicher ME, Sejr MK, Hogslund S (2013) Population structure of Mytilus edulis in the intertidal zone in a sub-Arctic fjord, SW Greenland. Mar Ecol Prog Ser 487:89-100. https://doi.org/10.3354/ Meps 10317

Cottier F, Tverberg V, Inall M et al (2005) Water mass modification in an Arctic fjord through cross-shelf exchange: the seasonal hydrography of Kongsfjorden, Svalbard. J Geophys Res 110:C12005. https://doi.org/10.1029/2004JC002757

Cottier FR, Nilsen F, Inall ME et al (2007) Wintertime warming of an Arctic shelf in response to large-scale atmospheric circulation. Geophys Res Lett 34:L10607. https://doi.org/10.1029/2007G L029948

Dyke AS, Dale JE, McNeely RN (1996) Marine molluscs as indicators of environmental change in glaciated North America and Greenland during the last 18000 years. Géographie Phys Quat 50:125. https://doi.org/10.7202/033087ar

Gillikin DP, Dehairs F, Lorrain A et al (2006) Barium uptake into the shells of the common mussel (Mytilus edulis) and the potential for estuarine paleo-chemistry reconstruction. Geochim Cosmochim Acta 70:395-407. https://doi.org/10.1016/j.gca.2005.09.015 
Gosling E (1992) The mussel Mytilus: ecology, physiology, genetics, and culture. Elsevier, Amsterdam

Gosling E (2003) Bivalve Culture. Bivalve Molluscs. Blackwell Publishing Ltd, Oxford, pp 284-332

Hjort C, Funder S (1974) The subfossil occurrence of Mytilus edulis L. in central East Greenland. Boreas 3:23-33. https://doi. org/10.1111/j.1502-3885.1974.tb00664.x

Hjort C, Mangerud J, Adrielsson L et al (1995) Radiocarbon dated common mussels Mytilus edulis from eastern Svalbard and the Holocene marine climatic optimum. Polar Res 14:239-243. https ://doi.org/10.1111/j.1751-8369.1995.tb00691.x

Hubbs CL (1952) Antitropical distribution of fishes and other organisms. Proc Seventh Pacif Sci Cong 3:324-329

Koehn RK (1991) The genetics and taxonomy of species in the genus Mytilus. Aquaculture 94:125-145. https://doi.org/10.1016/00448486(91)90114-M

Kortsch S, Primicerio R, Beuchel F et al (2012) Climate-driven regime shifts in Arctic marine benthos. Proc Natl Acad Sci USA 109:14052-14057. https://doi.org/10.1073/pnas.1207509109

Mangerud J, Svendsen JI (2018) The holocene thermal maximum around Svalbard, Arctic North Atlantic; molluscs show early and exceptional warmth. Holocene 28:65-83. https://doi. org/10.1177/0959683617715701

Mathiesen SS, Thyrring J, Hemmer-Hansen J et al (2017) Genetic diversity and connectivity within Mytilus spp. in the subarctic and Arctic. Evol Appl 10:39-55. https://doi.org/10.1111/eva.12415

Renaud PE, Carroll ML, Ambrose WG Jr (2007) Effects of global warming on Arctic sea-floor communities and its consequences for higher trophic levels. In: Duarte C (ed) Impactos del calentamiento global sobre los ecosistemas polares. FBBVA Press, Bilbao

Renaud PE, Sejr MK, Bluhm B et al (2015) The future of Arctic benthos: expansion, invasion, and biodiversity. Prog Oceanogr 139:244-257. https://doi.org/10.1016/j.pocean.2015.07.007

Salvigsen O (2002) Radiocarbon-dated Mytilus edulis and Modiolus modiolus from northern Svalbard: climatic implications. Nor Geogr Tidsskr 56:56-61. https://doi.org/10.1080/0029195027 60056350
Salvigsen O, Forman SL, Miller GH (1992) Thermophilous molluscs on Svalbard during the Holocene and their paleoclimatic implications. Polar Res 11:1-10

Sarnthein M, Van Kreveld S, Erlenkeuser H et al (2003) Centennial-tomillennial-scale periodicities of Holocene climate and sediment injections off the western Barents shelf, $75^{\circ} \mathrm{N}$. Boreas 32:447461. https://doi.org/10.1080/03009480310003351

Seed R (1969) The ecology of Mytilus edulis L. (Lamellibranchiata) on exposed rocky shores. Oecologica 3:277-316

Thyrring J, Rysgaard S, Blicher ME, Sejr MK (2015) Metabolic cold adaptation and aerobic performance of blue mussels (Mytilus edulis) along a temperature gradient into the High Arctic region. Mar Biol 162:235-243. https://doi.org/10.1007/s00227-014-2575-7

Vermeij GJ (1991) Anatomy of an invasion; the trans-Arctic interchange. Paleobiology 17:281-307

Ware C, Berge J, Sundet JH et al (2014) Climate change, non-indigenous species and shipping: assessing the risk of species introduction to a high-Arctic archipelago. Divers Distrib 20:10-19. https ://doi.org/10.1111/ddi.12117

Ware C, Berge J, Jelmert A et al (2016) Biological introduction risks from shipping in a warming Arctic. J Appl Ecol 53:340-349. https ://doi.org/10.1111/1365-2664.12566

Werner K, Spielhagen RF, Bauch D et al (2011) Atlantic water advection to the eastern fram strait-multiproxy evidence for late Holocene variability. Palaeogeogr Palaeoclimatol Palaeoecol 308:264276. https://doi.org/10.1016/j.palaeo.2011.05.030

Werner K, Spielhagen RF, Bauch D et al (2013) Atlantic Water advection versus sea-ice advances in the eastern Fram Strait during the last $9 \mathrm{ka}$ : multiproxy evidence for a two-phase Holocene. Paleoceanography 28:283-295. https://doi.org/10.1002/palo.20028

Weslawski JM, Wiktor J, Zajączkowski M, Swerpel S (1993) Intertidal zone of Svalbard: macroorganism distribution and biomass. Polar Biol 13:73-79

Weslawski JM, Zajaczkowski M, Wiktor J, Szymelfenig M (1997) Intertidal zone of Svalbard. Polar Biol 13:45-52 